\title{
Protamine-Derived Synthetic Peptide Enhances the Efficiency of Sperm-Mediated Gene Transfer Using Liposome-Peptide-DNA Complex
}

\author{
Tomohiro YONEZAWA ${ }^{1)}$, Yasufumi FURUHATA ${ }^{1 \#)}$, Keiji HIRABAYASHI'), \\ Masatoshi SUZUKI'), Keitaro YAMANOUCHI ${ }^{1)}$ and Masugi NISHIHARA ${ }^{1)}$ \\ ${ }^{1)}$ Department of Veterinary Physiology, Veterinary Medical Science, The University of Tokyo, \\ Tokyo 113-8657, Japan \\ \#Present: Ajinomoto Central Research Laboratories, Ajinomoto Co., Inc., Kawasaki 210-0801, \\ Japan
}

\begin{abstract}
Sperm-mediated gene transfer (SMGT), which uses sperm cells as vectors for DNA delivery during fertilization, is one of the methods used to achieve transgenesis in animals as an alternative to pronuclear microinjection. Despite the convenience of SMGT, its application in producing transgenic animals, especially domestic animals, is still limited due to its low success rate. In this study, to increase the efficiency of SMGT, we tested liposome-peptide-DNA (LPD) complex, a new reagent known to stabilize transfection in cultured cells. Two peptides, one designed from the amino acid sequence of human histone $\mathrm{H} 1 \mathrm{(Hs)}$ and the other from human protamine (Pr), were used with a $\mathrm{CMV} / \beta$-actin/EGFP fusion gene to form LPD complex. Spermatozoa obtained from rat epididymis were incubated with LPD complex and used for artificial insemination, and the expression of EGFP in the morula-stage embryos was observed. Pr caused significantly more embryos to express EGFP, while Hs had no effect on the expression rate. Moreover, only Pr resulted in the production of offspring carrying foreign DNA. These results suggest that LPD complex with the aid of Pr could be useful in the transfer of foreign DNA by SMGT, probably by stabilizing liposome-DNA complex during fertilization.
\end{abstract}

Key words: Gene transfer, Sperm vector, Peptide, Liposome, EGFP

(J. Reprod. Dev. 48: 281-286, 2002)

$\mathbf{G}$ ene transfer in mammals has been achieved using different methodologies. The most widespread method has been microinjection of DNA into pronuclei of fertilized 1-cell stage eggs [1-4], even though this method requires special equipment and skills. One of the more convenient alternatives is sperm-mediated gene transfer (SMGT), which uses spermatozoa as vectors for DNA delivery [5]. A large number of transgenic animals including mice, pigs and cattle have been

Accepted for publication: January 21, 2002

Correspondence: M. Nishihara. produced by SMGT using sperm associated with naked DNA or liposome-DNA complex [6-12]. However, the efficiency and reliability of SMGT are still controversial $[13,14]$, though the capacity of spermatozoa capturing foreign DNA has been proven $[15,16]$.

When cultured cells are transfected with DNA, various cationic liposomes are now widely used due to their considerable efficacy in transfection $[17,18]$. However, the efficacy of cationic liposomes for gene transfer in vivo is still limited and, therefore, several attempts have been made to 
give DNA-liposome complexes a resistance to factors that decrease their stability. Among them, one successful strategy was the addition of short synthetic peptides derived from motifs of nuclear DNA-binding proteins to liposome-DNA complexes in an attempt to induce DNA compaction. The application of liposome-peptideDNA (LPD) complexes has been demonstrated to enhance the efficiency of gene transfer both in vivo and in vitro $[19,20]$.

The aim of the present study was therefore to elucidate if the addition of synthetic peptides to liposome-DNA complexes could improve the efficiency of SMGT. Two peptides having amino acid motifs from histone and protamine, respectively, were used to form LPD complexes, and the expression of the transgene in early embryos as well as its integration into postpartum progeny were examined following SMGT.

\section{Materials and Methods}

\section{DNA (CMV/ $\beta$-Actin/EGFP), liposome and peptides}

The plasmid ( $\mathrm{pCX}-\mathrm{EGFP})$, containing cytomegalovirus (CMV) enhancer, chicken $\beta$-actin promoter, EGFP cDNA and rabbit $\beta$-globin 3' flanking sequence, was generously donated by Dr. Okabe (Genome Information Research Center, Osaka University) [21]. The plasmid DNA was purified by a Plasmid Purification System (Qiagen, Hilden, Germany) and then linearized using SalI. After enzymatic digestion, the linearized plasmid DNA was purified by phenol-chloroform extraction and then ethanol-precipitated. The cationic liposome, SuperFect, was purchased from Qiagen (Hilden, Germany).

Two peptides were designed from the report by Schwartz et al. [20], and chemically synthesized and purified by the Peptide Institute (Osaka, Japan). One peptide was the dimeric sequence (KTPKKAKKP) 2 (subsequently "Hs") corresponding to the amino acid residues of 152160 of human histone H1. This highly conserved sequence is repeated in the carboxyl-terminus of histones $\mathrm{H} 1$ of various species and its dimeric structure had been reported to alter the conformation of short double-stranded linear DNA fragments [22], resulting in an increase in the half life of DNA. The other peptide was a protaminederived amino acid sequence,
SRSRYYRQRQRSRRRRRR (subsequently "Pr"), which corresponds to the amino acid residues of 11-28 of human protamine 1. These two peptides were shown to induce DNA compaction when mixed with DNA, and thereby protected DNA from degradation by DNase [20]. The usefulness of these two peptides in increasing the efficiency of transfecting cultured cells or in vivo gene transfer was demonstrated previously [20].

\section{Sperm Vector by LPD complex and Artificial}

\section{Insemination}

The medium used for artificial insemination (AM) was modified from Whittingham medium [23]: $120 \mathrm{mM} \mathrm{NaCl}, 25 \mathrm{mM} \mathrm{NaHCO} 3,5 \mathrm{mM}$ Glucose, $2.5 \mathrm{mM} \mathrm{KCl}$ and $0.15 \mathrm{mM} \mathrm{Na}_{2} \mathrm{HPO}_{4}(\mathrm{pH}$ 7.4). Linearized plasmid DNA (10 $\mu \mathrm{g})$ dissolved in $500 \mu \mathrm{l}$ of filter-sterilized AM was mixed with $10 \mu \mathrm{g}$ of each peptide and incubated for $15 \mathrm{~min}$ at room temperature. Then the DNA-peptide solution was mixed SuperFect $(50 \mu \mathrm{l})$ dissolved in $500 \mu \mathrm{l}$ of AM with and incubated for more than $15 \mathrm{~min}$.

Wistar-Imamichi strain rats at the age of 7-8 weeks old were purchased from Animal Reproduction Laboratory (Omiya, Japan). Male rats were sacrificed by decapitation and epididymides were excised. Spermatozoa (approx. 1-2 million) were prepared by squeezing each cauda epididymis into $1 \mathrm{ml}$ of AM containing LPD complex. The sperm suspension was incubated with LPD complex for $1 \mathrm{~h}$ at $37 \mathrm{C}$ under air $/ \mathrm{CO}_{2}$ $(19: 1)$ for capacitation and DNA-binding to the sperm.

The uterine cervix of female rats was stimulated with a glass rod to induce pseudopregnancy on the proestrous evening. After preparation of the sperm suspension with LPD complex, the female rats were anesthetized by pentobarbital. An incision was made on the skin to expose the uterus and then 500 $\mu 1$ of suspended sperm/LPD complex was inseminated into each oviductal end of the uterus.

\section{Observation of EGFP expression in early embryos}

Some of the artificially inseminated female rats were killed by decapitation 4 days after the insemination, and uteri were excised. The uteri were flushed with saline to collect the embryos, and they were collected in a microdrop of saline. Expression of EGFP in the embryos was examined under a fluorescence microscope (E800, Nikon) with a GFP excitation light (490 nm). 
PCR analysis of the offspring

Detection of transferred DNA in the progeny was done by PCR analysis. Offspring from two female rats of each experimental condition were used (no peptide, $\mathrm{Hs}$ and $\mathrm{Pr}$, respectively). Genomic DNA was extracted from tails of 1-month -old pups. The tissue was lysed in $500 \mu \mathrm{l}$ of lysis buffer $(30 \mathrm{mM}$ Tris-Cl, $15 \mathrm{mM}$ EDTA, $0.3 \%$ SDS, $0.2 \mathrm{mg} / \mathrm{ml}$ proteinase $\mathrm{K}$ ) at $37 \mathrm{C}$ overnight. The DNA was purified by phenol-chloroform extraction and then ethanol-precipitated.

The PCR primers designed to amplify a 548-bp fragment from the promoter sequence of pCXEGFP were as follows: 5' CTGCTAACCATGTTCATGCC-3' (5' primer) and 5'-CGTTGTGGCTGTTGTAGTTG-3' (3' primer). The $25 \mu \mathrm{l}$ of PCR mixture consisted of reaction buffer (10 mM Tris-Cl (pH 8.3), $1.5 \mathrm{mM} \mathrm{MgCl}_{2}, 50$ $\mathrm{mM} \mathrm{KCl}, 0.01 \%$ gelatin, Bio-Rad, Hercules, CA, USA), $200 \mu \mathrm{M}$ of each dNTP, $50 \mathrm{pM}$ of each PCR primer and $0.1 \mu \mathrm{l}$ of Ampli Taq Gold polymerase (5 $\mathrm{U} / \mu \mathrm{l}$, Perkin-Elmer, Branchburg, NJ, USA) and 0.25 $\mu \mathrm{g}$ of the extracted DNA. PCR amplification was carried out for 35 cycles of $1 \mathrm{~min}$ at $94 \mathrm{C}, 1 \mathrm{~min}$ at $60 \mathrm{C}$ and $1 \mathrm{~min}$ at $75 \mathrm{C}$. The reaction was then analyzed on a $1.5 \%$ agarose gel, followed by ethidium bromide staining. The amplified DNA fragments were visualized by ultraviolet transillumination.

\section{Statistical analysis}

The data were analyzed by Duncan's multiple range test or chi-square test, and differences were considered significant at $\mathrm{P}<0.05$.

\section{Results}

\section{Expression of EGFP in transfected embryos}

A total of 13 female rats were artificially inseminated (Hs, 4; $\mathrm{Pr}, 6$; no peptide, 3 females).

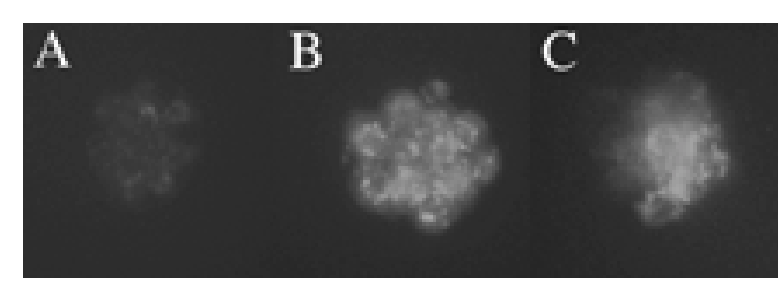

Fig. 1. Representative microscopic pictures of the morulastage embryos derived from SMGT using LPD complexes. Spermatozoa suspended with LPD complexes were inseminated artificially. At day 4 p.i., the uterus was flushed to collect embryos. The embryos in a microdrop of saline were observed under a fluorescence microscope. Fluorescent images were taken under an EGFP excitation light $(490 \mathrm{~nm})$. A, intact embryo; B, embryo with uniform expression (Pr was used); C, embryo with mosaic expression (Pr was used).

The number of collected embryos per uterus was not different among experimental groups (Hs, $9.0 \pm$ 1.7; $\operatorname{Pr}, 11.2 \pm 2.6$; no peptide, $11.2 \pm 1.2$ embryos). EGFP expression in embryos of day 4 postinsemination (p.i.) was examined under a fluorescence microscope. The representative pictures of EGFP expressing morula-stage embryos are shown in Fig. 1. As shown in Table 1, the ratio of EGFP expressing embryos to total embryos examined was about $75 \%$ when Pr was used, and this percentage was significantly higher than in the other conditions. Some of the embryos positive for EGFP showed mosaic expression. The ratios of the number of mosaic embryos to total EGFPexpressing ones were not significantly different among the peptide conditions.

\section{Detection of Transgene in the Offspring by PCR}

Females delivered 9-13 offspring in each experimental group. The existence of foreign DNA in 1-month-old offspring was examined by PCR. The results of PCR analysis are summarized in Table 2. Twenty-one pups (12 from one female, and 9 from the other) were obtained when Pr was used

Table 1. EGFP expression in the embryos

\begin{tabular}{lccc}
\hline Day 4 p.c. & $\begin{array}{c}\mathrm{Hs} \\
+/ \mathrm{n}(\%)\end{array}$ & $\begin{array}{c}\text { Pr } \\
+/ \mathrm{n}(\%)\end{array}$ & $\begin{array}{c}\text { No peptide } \\
+/ \mathrm{n}(\%)\end{array}$ \\
\hline Incidence of expression $^{\mathrm{a}}$ & $18 / 36(50.0)$ & $50 / 67^{*}(74.6)$ & $17 / 35(48.6)$ \\
${\text { Incidence of } \text { mosicism }^{\mathrm{b}}}$ & $11 / 18(61.1)$ & $26 / 50(52.0)$ & $12 / 17(70.6)$ \\
\hline
\end{tabular}

a Number of EGFP-expressing samples/number of samples examined.

${ }^{b}$ Number of mosaic samples/number of EGFP-expressing samples.

${ }^{*} \mathrm{p}<0.05$ vs. Hs and No peptide. 
Table 2. DNA Detection in the Progeny

\begin{tabular}{ccc}
\hline $\begin{array}{c}\text { Hs } \\
+/ \mathrm{n}^{\mathrm{a}}\end{array}$ & $\begin{array}{c}\text { Pr } \\
+/ \mathrm{n}\end{array}$ & $\begin{array}{c}\text { No peptide } \\
+/ \mathrm{n}\end{array}$ \\
\hline $0 / 27$ & $1 / 21$ & $0 / 32$ \\
\hline
\end{tabular}

a Number of positive samples/number of samples examined.

to make LPD complex, and one pup was shown to carry the foreign DNA. In the other conditions, no pups were positive for foreign DNA. EGFP expression in pups was not observed in any of the experimental groups.

\section{Discussion}

The present study was undertaken to test if the addition of peptides into liposome-DNA complex could improve the expression rate of foreign gene transferred by SMGT in embryos. The use of LPD complex with lysine- or arginine-rich cationic peptides derived from histone or protamine has been shown to negate an inhibitory effect of extra environment, which surrounds LPD complex and affects its performance [20]. However, of the two peptides tested in the present study, Hs in the LPD complex did not affect the expression rate of EGFP in the embryos. The precise reason for this ineffectiveness of $\mathrm{Hs}$ is currently unknown. Previous in vivo gene transfer with LPD complex was carried out by injecting the complex intravenously $[19,24]$, while in the present SMGT experiment, the complex was exposed to an intrauterine/oviductal environment. Therefore, it is possible that factor in the uterus/oviduct inhibiting the efficiency of SMGT might be different from those involved in the intravenous gene delivery approach.

On the other hand, more than $70 \%$ of the SMGTderived embryos expressed EGFP when Pr was used. Since DNAs in spermatozoa are compacted by protamines [25], but not by histones as in somatic cells, it is possible that Pr might mimic the in vivo environment of DNAs present in spermatozoa, and protect foreign DNA from potential exposure to DNase activity during fertilization

In the present study, no progeny were shown to carry foreign DNA except in the case when Pr was used to prepare LPD complex. This result appears to contradict the high expression rate of EGFP (more than $70 \%$ ) observed in day 4 p.i. embryos, and suggests that most of the foreign DNA was be excluded in the course of embryonic development without integration into the innate chromosomes. In other words, the expression of EGFP in most of the early embryos might result from the transient transcription of extrachromosomal DNA, as has been commonly observed in other methods utilizing sperm vector $[8,26]$. However, it should be noted that one pup still preserved the foreign DNA in its tail DNA at one month after birth when Pr was used, suggesting that integration occurred at least in this particular animal.

In our previous study, we reported that exogenous DNA injected into testes as a liposome complex could be transferred into the egg via sperm by natural mating and integrated into the genome, and this method is called testis-mediated gene transfer (TMGT) [26-28]. We speculate that, if the $\mathrm{Pr}$ is added to liposome-DNA complex injected into testes in TMGT, greater transfer efficiency might be achieved.

In summary, the present study demonstrated that $\mathrm{Pr}$, a peptide derived from human protamine, could enhance the efficiency of SMGT when it was applied to liposome-DNA complex. The newly employed SMGT method with LPD complex could be suitable for generating transgenic animals, especially transgenic domestic animals. Further study is required to clarify the mechanism by which Pr in LPD complex potentiates the efficiency of gene transfer.

\section{Acknowledgements}

We thank Dr. M. Okabe, Genome Information Research Center, Osaka University, for the generous gift of the vector plasmid pCX-EGFP. This study was supported by "Research for the Future" Program, The Japan Society for the Promotion of Science (JSPS-RFTF97L00904). 


\section{References}

1. Brinster RL, Chen HY, Trumbauer ME, Yagle MK, Palmiter RD. Factors affecting the efficiency of introducing foreign DNA into mice by microinjecting eggs. Proc Natl Acad Sci USA 1985; 82: 4438-4442.

2. Hammer RE, Pursel VG, Rexroad CE Jr, Wall RJ, Bolt DJ, Ebert KM, Palmiter RD, Brinster RL. Production of transgenic rabbit, sheep and pigs by microinjection. Nature 1985; 315: 680-683.

3. Palmiter RD, Brinster RL. Germ-line transformaion of mice. Ann Rev Genet 1986; 20: 465-499.

4. Biery KA, Bondioli KR, DeMayo FJ. Gene transfer by pronuclear injection in the bovine. Theriogenol 1988: 29: 224 (abst.).

5. Brackett BG, Baranska W, Sawicki W, Koprowski H. Uptake of heterologous genome by mammalian spermatozoa and its transfer to ova through fertilization. Proc Natl Acad Sci USA 1971; 68: 353357.

6. Arezzo F. Sea urchin sperm as a vector of foreign genetic information. Cell Biol Int Rep 1989; 13: 391404.

7. Lavitrano M, Camaioni A, Fazio AM, Dolci S, Farace MG, Spadafora C. Sperm cells as vectors for introducing foreign DNA into eggs: Genetic transformation of mice. Cell 1989; 57: 717-723.

8. Lauria A, Gandolfi F. Recent advances in sperm cell mediated gene transfer. Mol Reprod Dev 1993; 36: 255-257.

9. Squires EJ, Drake D. Liposome-mediated DNA transfer to chicken sperm cells. Anim Biotech 1993; 4: 71-88.

10. Rottmann O, Antes R, Hofer P, Sommer B, Wanner G, Gorlach A, Grummt F, Pirchner F. Liposomemediated gene transfer via sperm cells. High transfer efficiency and persistence of transgenes by use of liposomes and sperm cells and a murine amplification element. J Anim Breed Genet 1996; 113: 401-411.

11. Lavitrano M, Forni M, Varzi V, Pucci L, Bacci ML, Stefano CD, Fioretti D, Zoraqi G, Moioli B, Rossi M, Lazzereschi D, Stoppacciaro A, Seren E, Alfani D, Cortesini R, Frati L. Sperm-mediated gene transfer: production of pigs transgenic for a human regulator of complement activation. Transplant proc 1997; 29: 3508-3509.

12. Lavitrano $M$, Stoppacciaro A, Bacci ML, Forni M, Fioretti D, Pucci L, Stefano CD, Lazzereschi D, Rughetti A, Ceretta S, Zannoni A, Rahimi H, Moioli B, Rossi M, Nuti M, Rossi G, Seren E, Alfani D, Cortesini R, Frati L. Human Decay Accelerating factor transgenic pigs for xenotransplantation obtained by sperm-mediated gene transfer. Transplant proc 1999; 31: 972-974.
13. Brinster RL, Sandgren EP, Behringer RR, Palmiter RD. No simple solution for making transgenic mice. Cell 1989; 59: 239-241.

14. Maione B, Lavitrano M, Spadafora C, Kiessling AA. Sperm-mediated gene transfer in mice. $\mathrm{Mol}$ Reprod Dev 1998; 50: 406-409.

15. Atkinson PW, Hines ER, Beaton S, Mathaei KI, Reed KC, Bradley MP. Association of exogenous DNA with cattle and insert spermatozoa in vitro. Mol Reprod Dev 1991; 29: 1-5

16. Zani M, Lavitrano M, French D, Lulli V, Maione B, Sperandino S, Spadafora C. The mechanism of binding of exogenous DNA uptake. Exp Cell Res 1995; 217: 57-64.

17. Felgner PL, Gadek TR, Holm M, Roman R, Chan HW, Wenz M, Northrop JP, Ringold GM, Danielsen M. Lipofection: a highly efficient, lipidmediated DNA-transfection procedure. Proc Natl Acad Sci U S A 1987; 84: 7413-7417.

18. Felgner JH, Kumar R, Sridhar CN, Wheeler CJ, Tsai YJ, Border R, Ramsey P, Martin M, Felgner PL. Enhanced gene delivery and mechanism studies with a novel series of cationic lipid formulations. $J$ Biol Chem 1994; 269: 2550-2561.

19. Li S, Rizzo MA, Bhattacharya S, Huang L. Characterization of cationic lipid-protamine-DNA (LPD) complexes for intravenous gene delivery. Gene Ther 1998; 5: 930-937.

20. Schwartz B, Ivanov MA, Pitard B, Escriou V, Rangara R, Byk G, Wils P, Crouzet J, Sherman D. Synthetic DNA-compacting peptides derived from human sequence enhance cationic lipid-mediated gene transfer in vitro and in vivo. Gene Ther 1999; 6: 282-292.

21. Okabe M, Ikawa M, Kominami K, Nakanishi T, Nishimune $Y$. 'Green mice' as a source of ubiquitous green cells. FEBS Letters 1997; 407: 313319.

22. Erad M, Lakhdar-Ghazal F, Amalric F. Repeat motifs which contain b-turns and modulate DNA condensation. Eur J Biochem 1990; 191: 19-26.

23. Whittingham DG. Culture of mouse ova. J Reprod Fertil Suppl 1971; 14: 7-21.

24. Hong K, Zheng W, Baker A, Papahadjopoulos D. Stabilization of cationic liposome-plasmid DNA complexes by polyamines and poly (ethylene glycol)-phospholipid conjugates for efficient in vivo gene delivery. FEBS Lett 1997; 400: 233-237.

25. Fuentes-Mascorro G, Serrano H, Rosado A. Sperm chromatin. Arch Androl 2000; 45: 215-225 Review.

26. Yonezawa T, Furuhata $Y$, Hirabayashi K, Suzuki M, Takahashi M, Nishihara $\mathbf{M}$. Detection of transgene in progeny at different developmental stages following testis-mediated gene transfer. Mol 
Reprod Dev 2001; 60: 196-201.

27. Chang K, Ikeda A, Hayashi K, Furuhata Y, Nishihara M, Ohta A, Ogawa S, Takahashi M.

Production of transgenic rats and mice by the testismediated gene transfer. J Reprod Dev 1999; 45: 29-36.
28. Chang K, Ikeda A, Hayashi K, Furuhata Y, Bannai M, Nishihara M, Ohta A, Ogawa S, Takahashi M. Possible mechanisms for the testis-mediated gene transfer as a new method for producing transgenic animals. J Reprod Dev 1999; 45: 37-42. 